Egyptian Journal of Aquatic Biology \& Fisheries

Zoology Department, Faculty of Science,

Ain Shams University, Cairo, Egypt.

ISSN $1110-6131$

Vol. 24(7): 349 - 362 (2020)

www.ejabf.journals.ekb.eg

\title{
Food Intake, Conversion Efficiency and Growth of Hamilton's Pethia Ticto (Ticto Barb) from a Himalayan Stream
}

\author{
Ravindra Singh' ${ }^{1}$ Chandi Prasad ${ }^{1}$, Stanzin Namtak ${ }^{1}$, Ramchander Merugu ${ }^{2}$, Akash Deep ${ }^{1}$, \\ Naveen Tripathi ${ }^{1}$, Rahul Kumar ${ }^{1}$ *
}

1. Department of Environmental Sciences, H.N.B. Garhwal University (A Central University), Srinagar Garhwal- 246174, Uttarakhand, India

2. Department of Biochemistry, Mahatma Gandhi University, Anneparthy, Nalgonda- 508254, Telangana State, India.

*Corresponding Author: rahul.khadwalia@gmail.com

ARTICLE INFO

Article History:

Received: May 2, 2020

Accepted: Oct. 22, 2020

Online: Nov. 15, 2020

Keywords:

Pethia ticto;

management;

Conversion efficiency;

Himalayan stream;

Garhwal Himalaya
ABSTRACT

Garhwal Himalaya has a wide network of aquatic bodies in the form of rivers, lakes, tributaries, reservoirs, wetlands and ponds. These water bodies harbor very good fish diversity hence can be used for intensive fish culture. Pethia ticto was collected with the help of casting net and other local fishing methods from the Khanda Gad, a tributary of Alaknanda River that is also an important tributary of River Ganga. The study on food consumption was made by offering the food items of known weight and number to fishes and careful observations were made. The initial and the final weights of the fishes were taken and the growth was calculated. Among artificial feed, soya meal fed groups showed the highest conversion ratio (7.21:1) and semolina (suji) fed groups showed the lowest $(6.95: 1)$ conversion ratio. The present work is to develop a scientific approach for the management and conservation of the important fish (Pethia ticto) of Garhwal Himalaya.

\section{INTRODUCTION}

Fish provides an outstanding food source of animal protein for human consumption (Pal et al., 2018). This protein is comparatively having high digestibility and a growthpromoting value in the human diet. It is estimated that $23 \%$ of the people in the developing countries are malnourished, because of the high intake of calorie-deficient diet in the form of cereals rather than a calorie-rich diet of meat, fish and egg (Muller and Krawinkel, 2005; FAO, 2015). This also applies to Garhwal Himalaya where there is an acute problem of malnutrition among the rural masses of the hilly region. Although agriculture is the major shareholder in feeding the population on Earth (FAO, 2017), the aquaculture production has become a considerable companion in this regard (FAO, 2014; FAO, 2016). Aquaculture has recently made a great stride forward, new areas of fish 
culture have been developed, and old culture systems have been rejuvenated and intensified (IARI, 1993).

The nutrition components and gross energy made available for cell maintenance, growth, locomotion and determined by the amount of food consumed, the fraction that is assimilated, and the nutrient contents of the food (Talbot, 1985). The relationship between fish and their food is affected by a complex interaction between a number of factors, which include temperature, light, salinity, fish size, activity and behavior, appetite, feeding regime, starvation, stress and type of food (Volkoff and Peter, 2006; Jobling, 2006; Moberg, 2011; Martins et al., 2012). The quantitative requirement of any food depends largely on its composition. The most efficient level of feeding is attained only when the correct supply of energy and essential nutrients are available in the proportions required by the fish for maintenance and growth. The basic principle of bioenergetics is relatively simple to grasp and can be stated as all energy acquired through the ingestion of food is ultimately lost as wastes in feces or by new body tissue (growth and energy gain). Thus, bioenergetics is concerned with the study of rates of energy intake and transformations within the organism and provides the physiological framework for the study of the relationship between feeding rates and growth rates of fish subjected to environmental conditions. Considerable research efforts have been directed towards the study of fish bioenergetics and growth. Measurements have been made of the different components of the energy budget for fish that have been used in fisheries research for a variety of purposes. A major benefit of energy budget is that they can be 'instantaneous' i.e. carried out relatively in a short time period comparable in duration to biological and cultural cycles (e.g. one feeding cycle, one day) (Kooijman, 2008; Lee $\boldsymbol{e t}$ al., 2018). This is of particular benefit in making a rapid prediction of effects on the growth of certain diet formulation or feed regime or acute culture stress. Suitable indigenous feed formulations may be prescribed to substitute fish protein, which is in short supply. Other major raw materials for fish food such as rice bran, oil cake, groundnut cakes, sesame cake, or soya bean cake could be available. Thus, the study of bioenergetics enables the investigation of problems related to fisheries management and production and has a central place within aquaculture research (Tuene and Nortvedt, 1995).

Many studies have shown that multiple feeding resulted in more efficient utilization of the food than a single feeding. The number of feedings per day and the time of feeding vary with species, size of fish, and environmental conditions. Two inter-related ways of expressing the efficiency of conversion of food to body weight gain are important. The one, usually expressed as a percentage, is the 'food utilization ratio' or 'food conversion efficiency', which is the ratio between the gain in weight and the ingested food. The reciprocal of this expression is 'food conversion ratio' which designates the amount of food required to obtain a unit weight of body gained. The study of food intake, 
conversion efficiency and growth rate in fish has created an immense interest among fish biologists, because of its application in resource management. A lot of work has been done on various aspects including the food intake, conversion efficiency and growth that include the work of Suresh (2003) on fish nutrition and feed research; Jobling $\boldsymbol{e t}$ al. (2006) on the monitoring feeding behavior and food intake; Volkoff and Peter (2006) on feeding behavior of fish and its control; Priestley et al. (2006) on the influence of feeding frequency on growth and body condition of the common Goldfish; Lall and Tibbetts, (2009) on nutrition, feeding, and behavior of fish; Kawarazuka (2010) contributed on fish intake, aquaculture, and small-scale fisheries to improving nutrition; Eriegha (2017) on factors affecting feed intake in cultured fish species; Bogard (2017) on higher fish but lower micronutrient intakes: Temporal changes in fish consumption from capture fisheries and aquaculture in Bangladesh and Marinda (2018) on dietary diversity determinants and contribution of fish to maternal and under five nutritional status in Zambia; but, not a single attempt has been made on the food intake, conversion efficiency and growth of Pethia ticto (Ticto barb) in the Uttarakhand. The present work was carried out to develop a scientific approach for the management and conservation of Pethia ticto of Garhwal Himalaya.

\section{MATERIALS AND METHODS}

\section{The Study Area}

The stream Khanda Gad is a spring-fed tributary of the Alaknanda River in the lower Himalaya. The stream Khanda Gad flows from an elevation of 2,143 m above m.s.l. southeast to the northeast direction and meets the Alaknanda at Bilkedar 520 above m.s.l. (Figure 1). The Khanda basin lies between latitude $30^{\circ} 6{ }^{\prime} 42^{\prime \prime} \mathrm{N}$ to $30^{\circ} 13$ ' 23 " $\mathrm{N}$ and longitude $78^{\circ} 41^{\prime} 48^{\prime \prime}$ E to $79^{\circ} 5^{\prime} 4^{\prime \prime}$ E covering an area of $96.7 \mathrm{Km}^{2}$. The stream has been named as Khanda Gad (720 m above m.s.1.) after the confluence of two-parent streams named, Kathalsyun (Nayal) Gad and Nanda Gad, $1 \mathrm{Km}$ upstream of Khanda Chatti. The stream has been channelized at some places for irrigation purposes. Human settlements exist in the lower and middle stretch of both the stream banks. On both sides of the stream, the mountain slopes have been extensively used for agriculture purposes, especially for paddy crops. Horticulture is also being practiced along the bank of the stream at some places. 


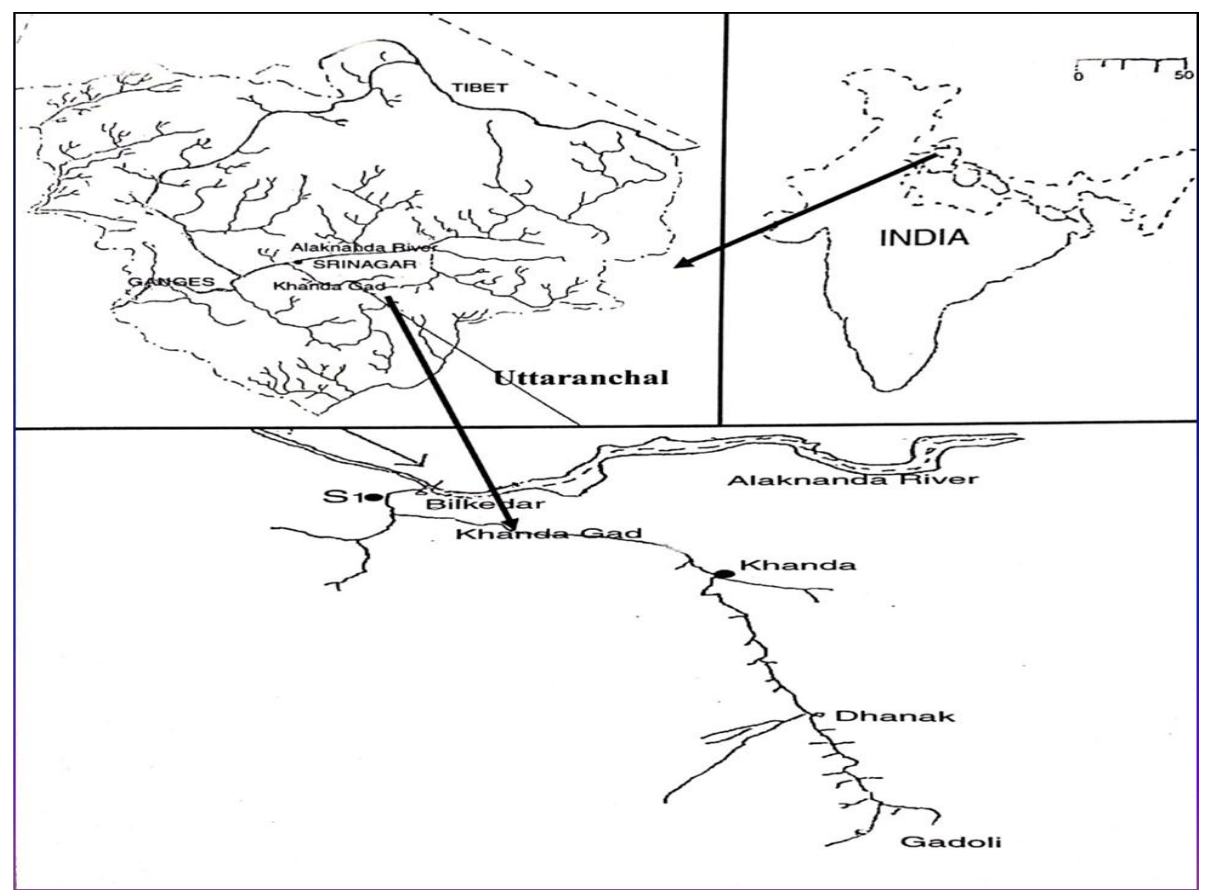

Figure 1. Location Map of the Study Area

\section{Fish sampling}

The fishes were collected from the Khanda Gad, a tributary of Alaknanda River near Bilkedar. The fishes were sampled with the help of casting net and other local fishing methods. These fishes were put in a bucket and brought to the laboratory in the Department of Environmental Sciences. All the fishes were divided into small groups and ten fishes in each group were reared on different food items in different aquaria. Four replicates were taken for each food item. The study on food consumption was made by offering items of foods of known weight and number to fishes and observed them carefully.

\section{Fish feeding}

This measurement was made by direct visual observation (Grove et al., 1978). When food consumption was measured by observation, the food was usually dispensed by hand. Fish may require a conditioning period before feeding regularly, and precautions were taken to avoid starving the fish during the feeding period. Observation of food items eaten may be facilitated using floating food. An alternative to observing the amount eaten is to measure the difference between the quantity offered and that remaining at the end of the feeding period (Wallace, 1973; Tytler and Calow, 1985). For this type of experiment, aquaria require a mesh to collect uneaten food in the effluent water.

\section{Growth determination}

Fishes were weighted to the nearest milligrams (mg) and divided into four groups of ten individuals in each for all the natural and artificial foods. For this study, the fishes were reared on these food items for 30 days. A weighted food was given to the entire Ad- 
libitum group, so that food was always available. Fishes were fed on the respective food combinations for 30 days. The uneaten food was removed from the aquaria through a fine sieve (diameter $160 \mu$ ) on the next day and was dried and weighed. After completion of the experiment, again the weights of the fish were measured for determining the growth and specific growth rate of each fish, using standard methods:

(i) Specific growth rate $\left(\%\right.$ day $\left.^{-1}\right)=\frac{\operatorname{In} W_{2}-\operatorname{In} W_{1} \times 100}{t_{2}-t_{1}}$

Where, $\mathrm{W}_{1}$ and $\mathrm{W}_{2}$ are fish weight, at time $\mathrm{t}_{1}$ and $\mathrm{t}_{2}$, respectively, and $\mathrm{t}_{2}-\mathrm{t}_{1}$ is the time, between weighing.

(ii) Feeding rate $\left(\mathrm{mg}\right.$ gm fish ${ }^{-1}$ day $\left.^{-1}\right)=$ Food consumed

$$
\text { Initial biomass } \times \text { days }
$$

The conversion efficiency $\left(\mathrm{K}_{1}\right)$ was expressed as a percentage and calculated following the methods outlined in Reddy et al. (1977):

$$
\text { Conversion efficiency }\left(\mathrm{K}_{1}\right)=\frac{\text { Growth } \times 100}{\text { Food intake }}
$$

Estimated food required and flesh production was calculated by the method details by Krishnan and Reddy (1984):

Estimated food required $(\mathrm{kg})=$ feeding rate $\times$ No. of days

Estimated flesh production $(\mathrm{kg})=$ estimated food required $\times$ specific growth rate $\times$ No. of individuals

Food conversion ratio $(\mathrm{kg})$ denotes the amount of dry food necessary to produce 1 $\mathrm{kg}$ of fish biomass:

Food conversion ratio $=\quad$ Total dry weight of food $(\mathrm{kg})$

Total wet weight $(\mathrm{t})$ gain $(\mathrm{Kg}) \times$ Biomass

\section{Statistical Treatment of Data}

The data was statistically treated with the help of standard statistical software (MS Excel, 2013) available. 


\section{RESULTS AND DISCUSSION}

The data on the initial biomass, yield total food consumption, food intake, feeding rate, growth, specific growth rate and conversion efficiency for Pethia ticto fed on four different types of natural food (macrozoobenthos, soya meal, semolina and oil cake) have been presented in Table 1-8. Different fish species may vary in their growth rates. Some species are capable of growing faster than others. A number of traits are affecting the growth, such as the capability of the fish to search for and utilize food, its ability to compete for food with other fish, and the physiological utilization attribute. All these are ultimately expressed in the growth rate of fish.

\section{Growth in Pethia ticto fed on macrozoobenthos}

Initially, the average weight of Pethia ticto fed on macrozoobenthos was recorded to be $3.469 \pm 0.1 \mathrm{gm}$ and the average final weight (yield) of the fishes was recorded to be $6.975 \pm 0.16 \mathrm{gm}$ by consuming $21.098 \pm 5.54 \mathrm{gm}$ of food (Table 1). The experimental fish consumed $79.49 \pm 0.13 \mathrm{mg}$ fish ${ }^{-1}$ day $^{-1}$ of natural food and the feeding rate was observed to be $229.35 \pm 8.27 \mathrm{mg} \mathrm{gm} \mathrm{fish}^{-1}$ day $^{-1}$. The growth was observed to be $11.086 \pm 0.53$, while the specific growth rate was computed to be $2.242 \pm 0.115 \%$ day $^{-1}$. However, the average conversion efficiency for natural food was calculated to be $13.947 \pm 0.141 \mathrm{~kg}$ and the food conversion ratio was computed to be 6.93:1 \pm 0.351 (Table 9). Observations on the present study revealed that the growth of Pethia ticto fed on natural food is higher than fish fed on artificial food like soya meal, semolina and oil cake. The feeding of natural food is higher (229.34 mg gm fish ${ }^{-1}$ day $^{-1}$ ) in comparison with the Channa gachua $(213.70 \mathrm{mg}$ $\mathrm{gm} \mathrm{fish}^{-1}$ day $^{-1}$ (Krishan and Reddy, 1983-84). The feeding rate of Pethia ticto was higher for the macrozoobenthos fed group and lower for the semolina fed group. However, the feeding rate of Pethia ticto under the present study was higher (171.16 mg gm per fish per day) than Barilius bendelisis (159.99 mg gm fish ${ }^{-1}$ day $\left.^{-1}\right)$. Under the present study, a linear relationship was found to occur between total food consumption and the specific growth rate of juveniles of Pethia ticto (Figure. 2). It is often possible to achieve a high rate of growth at the expense of excessive food and low utilization to make gain economical. 


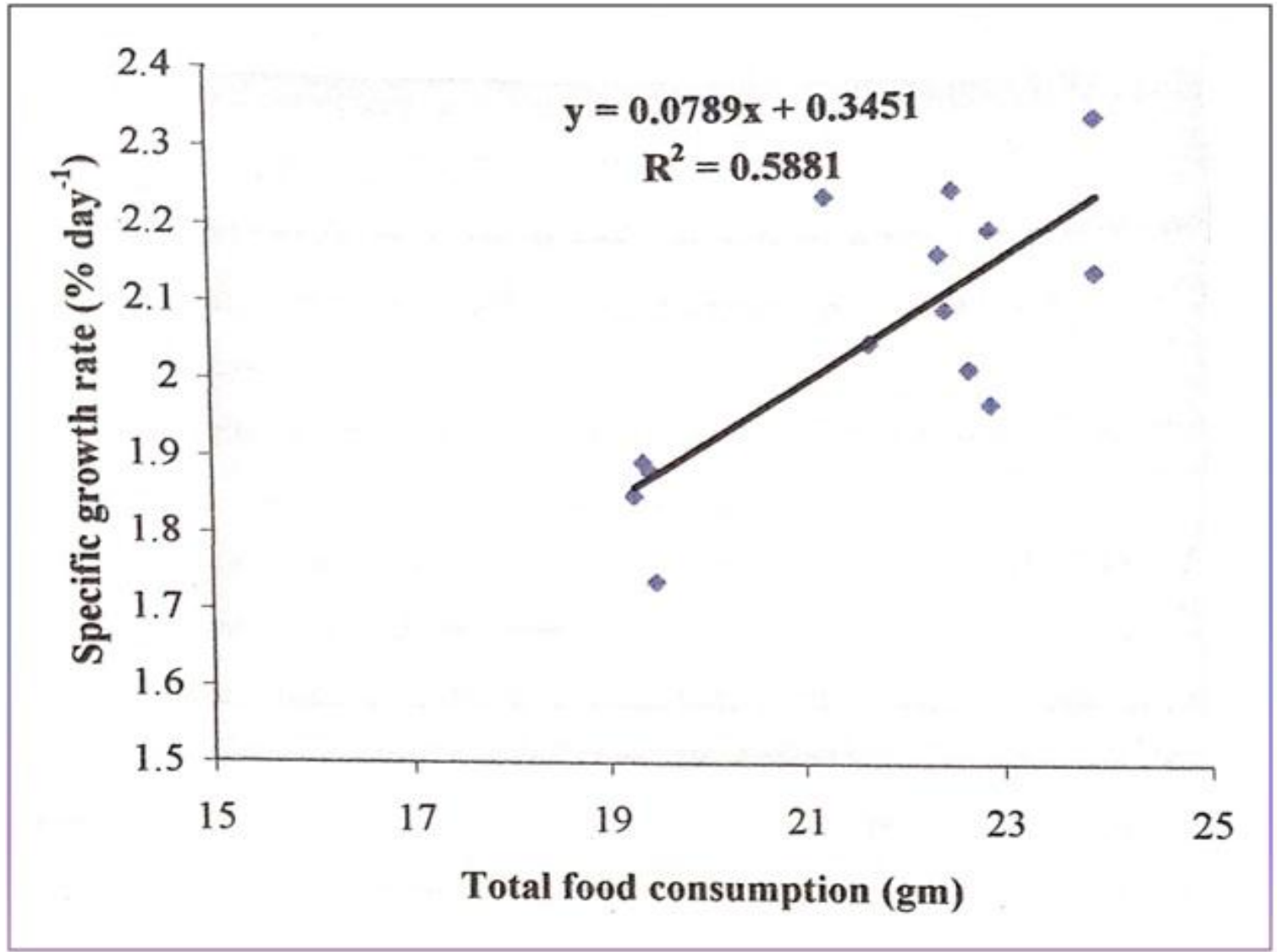

Figure 2. Average relationship between total consumption and specific growth rate

\section{Growth of Pethia ticto fed on Soya meal}

The average initial weight of the fishes reared on the soya meal was found to be $3.66 \pm 0.08 \mathrm{gm}$ and the yield was recorded to be $6.785 \pm 0.05 \mathrm{gm}$ after consuming $22.507 \pm 0.49 \mathrm{gm}$ of soya meal (Table 2). Food intake in Pethia ticto fed on soya meal was recorded to be $75.025 \pm 1.6481 \mathrm{mg}$ fish ${ }^{-1}$ day $^{-1}$, while the feeding rate was found to be $205.08 \pm 7.12 \mathrm{mg} \mathrm{gm} \mathrm{fish}{ }^{-1}$ day $^{-1}$. The growth was calculated to be $10.41 \pm 0.352 \mathrm{mg} \mathrm{fish}^{-1}$ day $^{-1}$; however, the specific growth rate of the fish was computed to be $2.056 \pm 0.084 \%$ day $^{-1}$. The conversion efficiency was found to be $13.88 \pm 0.580 \%$ (Table 6) and the average flesh production was computed to be $1.266 \pm 0.01 \mathrm{~kg}$ and the food conversion ratio was found to be 13.88:1 (Table 10). The artificial diet soya meal contains about $38 \%$ crude protein, $18 \%$ fat and $5 \%$ crude fiber. As with energy, the amount of protein required for maintenance can be measured by feeding fish a diet containing just enough protein to balance the loss due to the recycling of tissues, enzymes, etc, so that the protein content of the body will remain unchanged. Soya meal has a number of toxic stimulatory and inhibitory substances. It also contains genistein, a plant estrogen, which may account in some cases for part of its high growth-inducing properties. 


\section{Growth of Pethia ticto fed on Semolina}

The average biomass of Pethia ticto fed on semolina was recorded to be $3.776 \pm 0.07 \mathrm{gm}$ which resulted in a yield of $6.569 \pm 0.08 \mathrm{gm}$ by consuming $19.38 \pm 0.09 \mathrm{gm}$ of food (Table 3). The food intake by Pethia ticto fed on semolina was found to be $65.621 \pm 0.272 \mathrm{mg}$ fish $^{-1}$ day $^{-1}$, while the feeding rate was recorded to be $171.16 \pm 2.201 \mathrm{mg} \mathrm{gm} \mathrm{fish}^{-1}$ day $^{-1}$. The growth was recorded to be 9.3.9 $\pm 0.312 \mathrm{mg} \mathrm{fish}^{-1}$ day $^{-1}$ and the specific growth rate was computed to be $1.845 \pm 0.063 \%$ day $^{-1}$. However, the conversion efficiency was found to be $14.407 \pm 0.506 \%$ (Table 7 ). The average flesh production was recorded to be $0.948 \pm 0.049 \mathrm{~kg}$ and the food conversion ratio was noted to be $6.95: 1$ (Table 1). On average, the conversion efficiency $\left(\mathrm{K}_{1}\right)$ of Pethia ticto was recorded highest in semolina fed groups than other artificial food fed group. The food conversion ratio for Tor putitora fed on natural food was higher in respect to the soya meal, semolina and oil cake fed groups.

\section{Growth of Pethia ticto fed on Oil cake}

The average initial biomass of the fish reared on oil cake was found to be $3.352 \pm 0.10 \mathrm{gm}$ and the yield was noted to be $6.455 \pm 0.08$ gm by consuming $22.11 \pm 0.52 \mathrm{gm}$ of oil cake (Table 4). Food intake by Pethia ticto fed on oil cake was recorded to be $73.70 \pm 10.089$ $\mathrm{mg} \mathrm{fish}^{-1}$ day $^{-1}$ and the average feeding rate was found to be $219.92 \pm 5.229 \mathrm{mg} \mathrm{gm} \mathrm{fish}^{-1}$ day $^{-1}$. The growth of Pethia ticto fed on oil cake was recorded to be $10.34 \pm 0.127 \mathrm{mg}^{-1} \mathrm{sh}^{-}$ ${ }^{1} \mathrm{day}^{-1}$ and the specific growth rate was found to be $2.185 \pm 0.063 \% \mathrm{day}^{-1}$. However, the average conversion efficiency was computed to be $14.033 \pm 0.364 \%$ (Table 8). The average flesh production by Pethia ticto fed on oil cake was recorded to be $1.442 \pm 0.082$ gm and the food conversion ratio was computed to be 7.13:1 (Table 12). Oil cakes are in general a very good source of protein, about $95 \%$ of the nitrogen is present as true protein. It usually has a digestibility of $75 \%$ to $95 \%$. Certainly, they are of poorer quality than the better animal protein. The meals usually have high phosphorus content. Most fishes require $35-45 \%$ protein in their diet. Natural food (macrozoobenthos) however contains $50-60 \%$ protein (dry matter basis). When the fish live on natural food alone, this excessive food of protein is utilized for energy. This may be advantageous from a biological point of view since protein has a higher calorific value than supplementary carbohydrate, but it is wasteful from an economic point of view since protein is much more expensive than carbohydrate. Supplementary food must fill energy deficit first. At this stage, high energy-low protein diet can be used. If the fish have no difficulty in digesting and utilizing starch, as in the case with common carp, a starchy diet is usually the most economical. Where difficulties in digesting the starch exist, lipid can be a good source of energy.

A few studies have been made on the actual efficiency of food utilization for growth by actively feeding fish and on the effect of the diet composition, feeding level, and 
environmental conditions. It was also found that the utilization of carbohydrates by common carp for production of body fat to be $30 \%$ of the gross energy ingested, or if metabolizable energy is considered to be about $75 \%$ of the gross energy, this amounts to $40 \%$ of the metabolizable energy. This efficiency of utilization of dietary energy for growth is affected by the amount of food consumed. The cost of food amounts to a large proportion of the production costs of animals on culture, and the food conversion efficiency should be maximized. The food conversion efficiency was however better explained by growth than by consumption. This probably reflects the individual variation in the allocation of food to grow. This variation could have been caused by differences in energy losses in metabolism, feces and excretory products. A positive correlation was found between the feeding rate and specific growth rate for all the four types of food (Table 13). The feeding rate is not the only factor responsible for better growth but stress, food choice, quality and quantity of food, temperature and other favorable environmental conditions contribute to effect.

Table 1. Balance sheet of Ticto barb (Hamilton, 1822) reared on Natural food for 30 days

\begin{tabular}{|c|c|c|c|}
\hline $\begin{array}{c}\text { Group/Food } \\
\text { Type }\end{array}$ & $\begin{array}{c}\text { Initial Biomass } \\
\mathbf{( g m})\end{array}$ & Yield (gm) & $\begin{array}{c}\text { Total Food Consumption } \\
\text { (gm) }\end{array}$ \\
\hline $\mathrm{A}$ & 3.6468 & 6.9565 & 23.855 \\
\hline $\mathrm{B}$ & 3.4020 & 6.8946 & 12.790 \\
\hline $\mathrm{C}$ & 3.3529 & 6.7404 & 23.870 \\
\hline $\mathrm{D}$ & 3.4758 & 6.5890 & 23.875 \\
\hline $\bar{X}_{ \pm} \mathrm{SD}$ & $3.4694 \pm 0.1$ & $6.7951 \pm 0.16$ & $21.098 \pm 5.54$ \\
\hline
\end{tabular}

Table 2. Balance sheet of Ticto barb (Hamilton, 1822) reared on Soyameal for 30 days

\begin{tabular}{|c|c|c|c|}
\hline $\begin{array}{c}\text { Group/Food } \\
\text { Type }\end{array}$ & $\begin{array}{c}\text { Initial Biomass } \\
\mathbf{( g m})\end{array}$ & Yield (gm) & $\begin{array}{c}\text { Total Food Consumption } \\
\mathbf{( g m})\end{array}$ \\
\hline $\mathrm{A}$ & 3.7131 & 6.7026 & 22.870 \\
\hline $\mathrm{B}$ & 3.7189 & 6.8049 & 22.656 \\
\hline $\mathrm{C}$ & 3.6833 & 6.8258 & 21.662 \\
\hline $\mathrm{D}$ & 3.5266 & 6.8078 & 22.841 \\
\hline $\bar{X} \pm \mathrm{SD}$ & $3.6605 \pm 0.08$ & $6.7853 \pm 0.05$ & $22.507 \pm 0.49$ \\
\hline
\end{tabular}

Table 3. Balance sheet of Ticto barb (Hamilton, 1822) reared on Suji for 30 days

\begin{tabular}{|c|c|c|c|}
\hline $\begin{array}{c}\text { Group/Food } \\
\text { Type }\end{array}$ & $\begin{array}{c}\text { Initial Biomass } \\
\mathbf{( g m})\end{array}$ & Yield (gm) & $\begin{array}{c}\text { Total Food Consumption } \\
\mathbf{( g m})\end{array}$ \\
\hline $\mathrm{A}$ & 3.7275 & 6.5013 & 19.265 \\
\hline $\mathrm{B}$ & 3.7821 & 6.6870 & 19.365 \\
\hline $\mathrm{C}$ & 3.7264 & 6.5669 & 19.432 \\
\hline $\mathrm{D}$ & 3.8688 & 6.5211 & 19.484 \\
\hline $\bar{X} \pm \mathrm{SD}$ & $3.7762 \pm 0.07$ & $6.5691 \pm 0.08$ & $19.387 \pm 0.09$ \\
\hline
\end{tabular}


Table 4. Balance sheet of Ticto barb (Hamilton, 1822) reared on Oil cake for 30 days

\begin{tabular}{|c|c|c|c|}
\hline $\begin{array}{c}\text { Group/Food } \\
\text { Type }\end{array}$ & $\begin{array}{c}\text { Initial Biomass } \\
\mathbf{( g m})\end{array}$ & Yield (gm) & $\begin{array}{c}\text { Total Food Consumption } \\
(\mathbf{g m})\end{array}$ \\
\hline $\mathrm{A}$ & 3.4048 & 6.5140 & 22.343 \\
\hline $\mathrm{B}$ & 3.2350 & 6.3353 & 22.213 \\
\hline $\mathrm{C}$ & 3.2807 & 6.4344 & 21.476 \\
\hline $\mathrm{D}$ & 3.4904 & 6.5365 & 22.410 \\
\hline $\bar{X} \pm \mathrm{SD}$ & $3.3527 \pm 0.10$ & $6.4551 \pm 0.08$ & $22.111 \pm 0.52$ \\
\hline
\end{tabular}

Table 5. Food intake, feeding rate and specific growth rate of Ticto barb (Hamilton, 1822) reared on natural food (Algae and Macrozoobenthos) for 30 days in the laboratory

\begin{tabular}{|c|c|c|c|c|c|c|}
\hline Group & $\begin{array}{c}\text { Body weight } \\
\text { (mg) }\end{array}$ & $\begin{array}{c}\text { Food intake } \\
\left(\mathrm{mg} \mathrm{gm}^{-1}\right. \\
\left.\text { fish }^{-1} \text { day }^{-1}\right)\end{array}$ & $\begin{array}{l}\text { Feeding Rate } \\
\left(\mathrm{mg} \mathrm{gm}^{-1}\right. \\
\left.\text { fish }^{-1} \text { day }^{-1}\right)\end{array}$ & $\begin{array}{c}\text { Growth rate } \\
(\mathbf{m g} \\
\left.\text { fish }^{-1} \text { day }^{-1}\right)\end{array}$ & $\begin{array}{c}\text { Specific growth } \\
\text { rate } \\
\left(\% \text { day }^{-1}\right)\end{array}$ & $\begin{array}{c}\text { Conversion } \\
\text { efficiency } \\
\mathbf{K}_{1}(\%) \\
\end{array}$ \\
\hline A & 364.68 & 79.52 & 218.045 & 11.032 & 2.153 & 13.874 \\
\hline $\mathrm{B}$ & 340.20 & 79.30 & 233.098 & 11.642 & 2.355 & 14.681 \\
\hline $\mathrm{C}$ & 335.29 & 79.57 & 237.307 & 11.292 & 2.328 & 14.192 \\
\hline $\mathrm{D}$ & 347.58 & 79.58 & 228.964 & 10.378 & 2.132 & 13.040 \\
\hline$\overline{\bar{X}} \pm \mathrm{SD}$ & $346.94 \pm 12.86$ & $79.49 \pm 0.13$ & $229.354 \pm 8.273$ & $11.086 \pm 0.535$ & $2.242 \pm 0.116$ & $13.947 \pm 0.689$ \\
\hline
\end{tabular}

Table 6. Food intake, feeding rate and specific growth rate of Ticto barb (Hamilton, 1822) reared on Soyameal for 30 days in the laboratory

\begin{tabular}{|c|c|c|c|c|c|c|}
\hline Group & $\begin{array}{c}\text { Body weight } \\
\text { (mg) }\end{array}$ & $\begin{array}{l}\text { Food intake } \\
\left(\mathrm{mg} \mathrm{gm}^{-1}\right. \\
\left.\text { fish }^{-1} \text { day }^{-1}\right)\end{array}$ & $\begin{array}{l}\text { Feeding Rate } \\
\left(\mathrm{mg} \mathrm{gm}^{-1} \text { fish }^{-1} \text { day }^{-1}\right)\end{array}$ & $\begin{array}{c}\text { Growth rate } \\
(\mathbf{m g} \\
\left.\text { fish }^{-1} \text { day }^{-1}\right)\end{array}$ & $\begin{array}{c}\text { Specific } \\
\text { growth rate } \\
\left(\% \text { day }^{-1}\right)\end{array}$ & $\begin{array}{c}\text { Conversion } \\
\text { efficiency } \\
\mathbf{K}_{1}(\%)\end{array}$ \\
\hline $\mathrm{A}$ & 371.31 & 76.23 & 205.309 & 9.965 & 1.968 & 13.072 \\
\hline $\mathrm{B}$ & 371.89 & 75.52 & 203.071 & 10.280 & 2.014 & 13.612 \\
\hline $\mathrm{C}$ & 368.33 & 72.21 & 196.038 & 10.457 & 2.050 & 14.506 \\
\hline $\mathrm{D}$ & 352.66 & 76.14 & 215.890 & 10.937 & 2.192 & 14.360 \\
\hline$\overline{\bar{X}} \pm \mathrm{SD}$ & $366.05 \pm 7.85$ & $75.03 \pm 1.65$ & $205.080 \pm 7.118$ & $10.410 \pm 0.352$ & $2.056 \pm 0.084$ & $13.888 \pm 0.580$ \\
\hline
\end{tabular}

Table 7. Food intake, feeding rate and specific growth rate of Ticto barb (Hamilton, 1822) reared on Suji for 30 days in the laboratory

\begin{tabular}{|c|c|c|c|c|c|c|}
\hline Group & $\begin{array}{c}\text { Body weight } \\
\text { (mg) }\end{array}$ & $\begin{array}{l}\text { Food intake } \\
\left(\mathrm{mg} \mathrm{gm}^{-1} \text {. }^{-1}\right) \\
\left.\text { fish }^{-1} \text { day }^{-}\right)\end{array}$ & $\begin{array}{c}\text { Feeding Rate } \\
\left(\mathrm{mg} \mathrm{gm}^{-1} \text { fish }^{-1} \text { day }^{-1}\right)\end{array}$ & $\begin{array}{c}\text { Growth rate } \\
(\mathrm{mg} \\
\left.\text { fish }^{-1} \text { day }^{-1}\right)\end{array}$ & $\begin{array}{c}\text { Specific growth } \\
\text { rate } \\
\left(\% \text { day }^{-1}\right)\end{array}$ & $\begin{array}{c}\text { Conversion } \\
\text { efficiency } \\
K_{1}(\%)\end{array}$ \\
\hline $\mathrm{A}$ & 372.75 & 64.216 & 172.278 & 9.246 & 1.854 & 14.398 \\
\hline $\mathrm{B}$ & 378.21 & 64.550 & 170.672 & 9.683 & 1.899 & 15.001 \\
\hline $\mathrm{C}$ & 372.64 & 64.773 & 173.822 & 9.468 & 1.888 & 14.617 \\
\hline $\mathrm{D}$ & 386.88 & 64.946 & 167.873 & 8.841 & 1.470 & 13.613 \\
\hline $\bar{X} \pm \mathrm{SD}$ & $377.62 \pm 5.80$ & $64.621 \pm 0.273$ & $171.160 \pm 2.201$ & $9.309 \pm 0.311$ & $1.845 \pm 0.063$ & $14.407 \pm 0.507$ \\
\hline
\end{tabular}


Table 8. Food intake, feeding rate and specific growth rate of Ticto barb (Hamilton, 1822) reared on Oil cake for 30 days in the laboratory

\begin{tabular}{|c|c|c|c|c|c|c|}
\hline Group & $\begin{array}{c}\text { Body weight } \\
\text { (mg) }\end{array}$ & $\begin{array}{l}\text { Food intake } \\
\left(\mathrm{mg} \mathrm{gm}^{-1}\right. \\
\left.\text { fish }^{-1} \text { day }^{-1}\right)\end{array}$ & $\begin{array}{c}\text { Feeding Rate } \\
\left(\mathrm{mg} \mathrm{gm}^{-1} \mathrm{day}^{-1}\right) \\
\text { fish }^{-1} \text { (a) }^{2}\end{array}$ & $\begin{array}{c}\text { Growth rate } \\
(\mathrm{mg} \\
\left.\text { fish }^{-1} \text { day }^{-1}\right)\end{array}$ & \begin{tabular}{|} 
Specific growth \\
rate \\
$\left(\%\right.$ day $\left.^{-1}\right)$
\end{tabular} & $\begin{array}{c}\text { Conversion } \\
\text { efficiency } \\
\mathbf{K}_{1}(\%)\end{array}$ \\
\hline A & 340.48 & 74.48 & 218.740 & 10.364 & 2.163 & 13.910 \\
\hline $\mathrm{B}$ & 323.50 & 70.71 & 218.578 & 10.330 & 2.240 & 14.600 \\
\hline $\mathrm{C}$ & 328.07 & 74.92 & 228.366 & 10.512 & 2.245 & 14.031 \\
\hline $\mathrm{D}$ & 349.04 & 74.70 & 214.015 & 10.153 & 2.091 & 13.592 \\
\hline $\bar{X} \pm \mathrm{SD}$ & $335.27 \pm 10.09$ & $73.70 \pm 1.73$ & $219.920 \pm 5.229$ & $10.340 \pm 0.128$ & $2.185 \pm 0.063$ & $14.033 \pm 0.364$ \\
\hline
\end{tabular}

Table 9. Estimated food required, new flesh production $(\mathrm{kg})$ and conversion ratio of Ticto barb (Hamilton, 1822) fed on natural food (macrozoobenthos)

\begin{tabular}{|c|c|c|c|}
\hline Group & Food Required (kg) & New Flesh Production & Conversion Ratio \\
\hline A & 6.5414 & 1.408 & $7.20: 1$ \\
\hline B & 6.9929 & 1.649 & $6.53: 1$ \\
\hline C & 7.1192 & 1.657 & $7.05: 1$ \\
\hline D & 6.8689 & 1.464 & $7.66: 1$ \\
\hline $\bar{X} \pm$ SD & $6.8806 \pm 0.2481$ & $1.5445 \pm 0.1273$ & $7.11: 1 \pm 0.4656$ \\
\hline
\end{tabular}

Table 10. Estimated food required, new flesh production $(\mathrm{kg})$ and conversion ratio of Ticto barb (Hamilton, 1822) fed on Soya meal

\begin{tabular}{|c|c|c|c|}
\hline Group & Food Required (kg) & New Flesh Production & Conversion Ratio \\
\hline A & 6.1593 & 1.212 & $7.65: 1$ \\
\hline B & 6.0921 & 1.2277 & $7.34: 1$ \\
\hline C & 5.8811 & 1.206 & $6.89: 1$ \\
\hline D & 6.4767 & 1.419 & $6.96: 1$ \\
\hline $\bar{X} \pm$ SD & $6.1523 \pm 0.1452$ & $1.266 \pm 0.0108$ & $7.21: 1 \pm 0.3821$ \\
\hline
\end{tabular}

Table 11: Estimated food required, new flesh production $(\mathrm{kg})$ and conversion ratio of Ticto barb (Hamilton, 1822) fed on Semolina

\begin{tabular}{|c|c|c|c|}
\hline Group & Food Required (kg) & New Flesh Production & Conversion Ratio \\
\hline A & 5.1683 & 0.958 & $6.95: 1$ \\
\hline B & 5.1202 & 0.972 & $6.67: 1$ \\
\hline C & 5.2146 & 0.985 & $6.84: 1$ \\
\hline D & 5.0362 & 0.876 & $7.35: 1$ \\
\hline $\bar{X} \pm$ SD & $5.1348 \pm 0.0762$ & $0.9478 \pm 0.0491$ & $6.95: 1 \pm 0.2889$ \\
\hline
\end{tabular}


Table 12. Estimated food required, new flesh production $(\mathrm{kg})$ and conversion ratio of Ticto barb (Hamilton, 1822) fed on Oil cake

\begin{tabular}{|c|c|c|c|}
\hline Group & Food Required (kg) & New Flesh Production & Conversion Ratio \\
\hline A & 6.5622 & 1.419 & $7.18: 1$ \\
\hline B & 6.5573 & 1.469 & $6.84: 1$ \\
\hline C & 6.8509 & 1.538 & $7.13: 1$ \\
\hline D & 6.4205 & 1.343 & $7.36: 1$ \\
\hline $\bar{X} \pm$ SD & $6.5977 \pm 0.1811$ & $1.4423 \pm 0.0822$ & $7.13: 1 \pm 0.2156$ \\
\hline
\end{tabular}

Table 13. Correlation between the feeding rate and specific growth rate of Ticto barb (Hamilton, 1822)

\begin{tabular}{|c|c|}
\hline Food Type & Coefficient of Correlation (r) \\
\hline $\begin{array}{c}\text { Natural Food (Algae and } \\
\text { Macrozoobenthos) }\end{array}$ & 0.750774 \\
\hline Soyameal & 0.66635 \\
\hline Suji & 0.79937 \\
\hline Oil cake & 0.76775 \\
\hline
\end{tabular}

\section{CONCLUSION}

Pethia ticto reared on natural food (macrozoobenthos) showed the highest growth $\left(11.086 \pm 0.535 \mathrm{mg}\right.$ fish ${ }^{-1}$ day $\left.^{-1}\right)$ and specific growth rate $\left(2.242 \pm 0.116 \%\right.$ day $\left.^{-1}\right)$. Oil cake and Soya meal showed a good growth rate to be $2.185 \pm 0.063 \%$ day $^{-1}$ and $2.056 \pm 0.084 \%$ day $^{-1}$ respectively. However, maximum conversion efficiency $(14.407 \pm 0.507 \%)$ was found in semolina and the lowest conversion efficiency was noted in the case of soya meal fed group of Pethia ticto. The food intake was highest $\left(79.49 \pm 0.13 \mathrm{mg}\right.$ fish $^{-1}$ day $\left.^{-1}\right)$ in natural food fed groups and lowest in semolina fed groups $\left(64.621 \pm 0.273 \mathrm{mg} \mathrm{fish}^{-1}\right.$ day $\left.^{-1}\right)$. Pethia ticto required $6.885 \pm 0.30 \mathrm{~kg}$ of natural food and resulted in $1.571 \pm 0.141 \mathrm{~kg}$ of flesh. Among artificial feed, the fish required $6.152 \pm 0.15 \mathrm{~kg}$ of soya meal resulting in the flesh production of $1.266 \pm 0.011 \mathrm{~kg}$. The fish required $5.134 \pm 0.076 \mathrm{~kg}$ of semolina and produced $0.9478 \pm 0.049 \mathrm{~kg}$ of flesh. The requirement of oil cake was noted to be $6.597 \pm 0.181 \mathrm{~kg}$ and the flesh production was computed to be $1.4423 \pm 0.082 \mathrm{~kg}$. The food conversion ratio was the highest (7.21:1) for soya meal fed groups and the lowest for natural food fed groups of Pethia ticto. Among artificial feed, soya meal fed groups showed the highest conversion ratio (7.21:1) and semolina fed groups showed the lowest (6.95:1) conversion ratio. The present study reveals that soya meal, semolina and oil cake have a high nutritive value and conversion efficiency. So, these experimental foods may be tried in addition to the natural food, for improving the growth of fish which will be instrumental for fish culture and fisheries management in Garhwal Himalaya. Thus, the present study has an applied value. 


\section{ACKNOWLEDGEMENT}

Three of the authors (Akash Deep, Chandi Prasad and Stanzin Namtak) are thankfully acknowledge for the fellowship given by the University Grant Commission, New Delhi through Hemvati Nandan Bahuguna Garhwal University (A Central University), Srinagar-Garhwal, Uttarakhand, India for undertaking the present work.

\section{REFERENCES}

Bogard, J.R.; Farook, S.; Marks, G.C.; Waid, J.; Belton, B.; Ali, M.; Toufique, K.; Mamun, A. and Thilsted, S.H. (2017). Higher fish but lower micronutrient intakes: Temporal changes in fish consumption from capture fisheries and aquaculture in Bangladesh. PLoS ONE 12(4): e0175098.

Eriegha, O.J. and Ekokotu, P.A. (2017). Factors affecting feed intake in cultured fish species: a review. Anim. Res. Int., 14(2): 2697 - 2709.

F.A.O. (2014). The State of World Fisheries and Aquaculture. Rome: Food and Agriculture Organization, pp: 1-243.

F.A.O. (2015). The State of Food Insecurity in the World. Rome: Food and Agriculture Organization, pp: 1-62.

F.A.O. (2016). The future of food and agriculture. Rome: Food and Agriculture Organization, pp: 1-180.

F.A.O. (2017). The State of World Fisheries And Aquaculture: Contributing to food security and nutrition for all. Rome: Food and Agriculture Organization, pp: 1204.

Grove, D.J.; Loizides, L.G. and Nott, J. (1978). Satiation amount, frequency of feeding and gastric emptying rate in Salmo gairdneri. J. Fish Biol., 12: 507-516.

I.A.R.I. (1993). Agriculture Policy: Vision 2020. Indian Agricultural Research Institute, New Delhi, pp: 1-19.

Jobling, M.; Arnesen, A.M.; Baardvik, B.M. and Christiansen, J.S. (2006). Monitoring feeding behavior and food intake: Methods and applications. Aquac. Nutr., 1(3): $131-143$.

Kawarazuka, N. (2010). The contribution of fish intake, aquaculture, and small-scale fisheries to improving nutrition: A literature review. The WorldFish Center, Penang, Malaysia, pp: 1-44.

Kooijman, S.A.L.M. (2008). Energetics and models. Dynamic Energy and Mass Budgets in Biological Systems. Cambridge University Press, $2^{\text {nd }}$ Ed, pp: 1-444.

Krishnan, N. and Reddy, S.R. (1984). Experimental studies on the utilization of natural good by juvenile Channa gachua (Pisces: Channidae). Matsya 9(10): 96-99.

Lall, S.P. and Tibbetts, S.M. (2009). Nutrition, Feeding, and Behavior of Fish. Vet. Clin. Exot. Anim., 12: 361-372. 
Lee, Y.J.; Han, E.; Wilberg, M.J. and Lee, W.C. (2018). Physiological processes and gross energy budget of the submerged longline-cultured Pacific oyster Crassostrea gigas in a temperate bay of Korea. PLOS One 13(7): 1-24.

Marinda, P.A.; Genschick, S.; Khayeka-Wandabwa, C.; Kiwanuka-Lubinda, R. and Thilsted, S.H. (2018). Dietary diversity determinants and contribution of fish to maternal and under-five nutritional status in Zambia. PLOS One 13(9): e0204009.

Martins, C.I.M.; $\quad$ Galhardo, L.; $\quad$ Noble, C.; $\quad$ Damsgård, B.; $\quad$ Spedicato, M.T.; Zupa, W.; Beauchaud, M.; Kulczykowska, E.; Massabuau, J.C.; Carter, T.; Planellas, S.R. and Kristiansen, T. (2012). Behavioural indicators of welfare in farmed fish. Fish Physiol. Biochem., 38(1): 17-41.

Muller, O. and Krawinkel, M. (2005). Malnutrition and health in developing countries. Can. Med. Assoc. J., 173(3): 279-286.

Olav Moberg, O.; Braithwaite, V.A.; Jensen, K.H. and Salvanes, A.G.V. (2011). Effects of habitat enrichment and food availability on the foraging behaviour of juvenile Atlantic Cod (Gadus morhua L). Environ. Biol. Fishes 91(4): 449-457.

Pal, J.; Shukla, B.N.; Maurya, A.K.; Verma, H.O.; Pandey, G. and Amitha. (2018). A review on role of fish in human nutrition with special emphasis to essential fatty acid. Int. J. Fish. Aquac., 6(2): 427-430.

Priestley, S.M.; Stevenson, A.E. and Alexander, L.G. (2006). Influence of Feeding Frequency on Growth and Body Condition of the Common Goldfish (Carassius auratus). American Society for Nutrition. J. Nutr., 136: 1979-1981.

Reddy, S.R.; Katre, S. and Rajgopal, K.V. (1977). Preliminary studies on the conversion of Tubifex tubifex as food by elvers of Anguilla nebulosa (Gray and Hardwicke). J. Fish Biol., 11: 279-281.

Suresh, V.R. (2003). Fish nutrition and feed research. Fishing Chimes 23(1): 78-81.

Talbot, C. (1985). Laboratory Methods in Fish Feeding and Nutritional Studies. In. Fish Energetics. Edt. Peter Tytler and Peter Calow, pp: 125-154.

Tuene, S. and Nortvedt, R. (1995). Feed intake, growth and feed conversion efficiency of Atlantic halibut, Hippoglossus hippoglossus (L.). Aquac. Nutr., 1(1): 27-35.

Tytler, P. and Calow, P. (1985). Fish Energetics. Springer Science. https://doi.org/10.1007/978-94-011-7918-8

Volkoff, H. and Peter, R.E. (2006). Feeding Behavior of Fish and Its Control. Zebrafish 3(2): 131-40.

Wallace, J.C. (1973). Feeding, starvation and metabolic rate in the shore crab Carcinus maenas. Mar. Biol., 20(4): 277-281. 